\title{
THE CLOT-PROMOTING EFFECT OF SOAPS OF LONG-CHAIN SATURATED FATTY ACIDS *
}

\author{
By ROBERT E. BOTTI $\dagger$ AND OSCAR D. RATNOFF $\ddagger$
}

(From the Department of Medicine, Western Reserve University School of Medicine and Unizersity Hospitals of Cleveland, Cleveland, Ohio)

(Submitted for publication April 22, 1963 ; accepted June 20, 1963)

Soaps of long-chain saturated fatty acids are said to accelerate the coagulation of mammalian plasma (1-6). Concentrations of soaps comparable to the concentration of free fatty acids found in human plasma shorten the recalcified clotting time and accelerate the formation of artificial thrombi in vitro $(5,6)$. Whether the free fatty acids normally present in human plasma serve a physiologic function in hemostasis is yet to be determined.

The mechanisms through which soaps of fatty acids promote clotting have not yet been clarified. Connor (6) proposed that soaps act to initiate clotting, behaving in a manner analogous to glass. Thus he believes that soaps, like glass, activate Hageman factor, an agent present in mammalian plasma. The experiments to be reported here do not support this view. They imply, on the contrary, that soaps probably act in a unique way by accelerating the formation of activated plasma thromboplastin antecedent (activated PTA) from its precursor, plasma thromboplastin antecedent (PTA), whether by activated Hageman factor or "spontaneously." Although the concentrations of free fatty acids in plasma may be abnormally high under conditions in which intravascular thrombosis is likely to occur $(7,8)$, the studies to be described do not provide evidence for a causal relationship.

\section{METHODS}

All studies were performed with blood, plasma, or plasma fractions that had been collected or prepared in silicone-coated tubes. Unless otherwise noted, direct contact with glass or similar clot-promoting substances was avoided.

* This study was supported in part by U. S. Public Health Service research grant H1661C, National Institutes of Health, and in part by a grant from the American Heart Association.

$\dagger$ American Heart Association Research Fellow in Medicine.

$\ddagger$ Career Investigator, American Heart Association.
V'enous blood was drawn from the antecubital veins of normal subjects or from patients with various hereditary coagulative disorders. No. 18-gauge needles coated with Siliclad ${ }^{1}$ and glass syringes coated with silicone ${ }^{2}$ were used.

Platelet-deficient citrated plasma was prepared from blood to which one-ninth vol of $0.13 \mathrm{M}$ trisodium citrate had been added (9) unless otherwise noted. Heated, adsorbed plasma was prepared by mixing 10 vol of plasma with 1 vol of aluminum hydroxide gel. ${ }^{3}$ This mixture was placed in a Lusteroid container in a $56^{\circ} \mathrm{C}$ water bath for $\frac{1}{2}$ hour and then centrifuged for 5 minutes at $3,700 \times g$ in an International refrigerated centrifuge $(\mathrm{PR}-2)$ at $2^{\circ} \mathrm{C}$. The supernatant plasma was decanted from the precipitated gel. Normal human plasma, prepared in this manner, is deficient in all known clotting factors except PTA (Factor XI) and Hageman factor (Factor XII) (9). Native plasma, free of extrinsic anticoagulants, was prepared by the method of Conley, Hartmann, and Morse (10). Plasma prepared this way remained fluid in silicone-coated tubes at $37^{\circ} \mathrm{C}$ from 40 minutes to more than 48 hours.

Crude PTA was prepared by a previously described method from citrated plasma deficient in Hageman factor (9). Freshly prepared, the PTA was largely inactive but usually contained some activated PTA; further activation occurred upon storage at $-20^{\circ}$ C. Partially' purified activated PT $A$ was prepared from normal human serum. As previously described (11), the carboxymethylcellulose column was washed with a volume of $0.15 \mathrm{M}$ sodium acetate buffer equal to one-half of the original serum. The elution was modified in that 800 $\mathrm{ml}$ of a buffer containing equal parts of $0.067 \mathrm{M}$ phosphate buffer ( $\mathrm{pH}$ 6.8) and $1 \mathrm{M}$ sodium chloride was used (12). Fractions were collected in $100-\mathrm{ml}$ volumes and were assayed for activated PTA (9). Those containing the major part of the PTA activity (usually fractions 4 and 5) were combined. The fraction soluble at $33 \%$ and insoluble at $50 \%$ concentration of ammonium sulfate was prepared by addition of a solution of neutral ammonium sulfate saturated at $4^{\circ}$ C. The salt was

1 Clay-Adams Co., Inc. New York, N. Y.

2 General Electric Co., Waterford, N. Y.

3 Provided through the courtesy of Cutter Laboratories, Berkeley, Calif. The concentration of aluminum hydroxide gel is expressed by the manufacturer as aluminum oxide. The gel used contained $0.6 \%$ aluminum oxide. 
added dropwise with constant stirring until the desired concentration was obtained. The precipitate was dissolved in a volume of $0.067 \mathrm{M}$ sodium phosphate buffer ( $\mathrm{pH}$ 6.8) equal to one-fiftieth of the original volume of serum. It was dialyzed overnight against $4 \mathrm{~L}$ of the same buffer and then lyophilized.

Purified activated Hageman factor was prepared from normal human plasma by a method previously published (13). This method utilized column chromatography with carboxymethylcellulose and DEAE cellulose, resulting in a product purified 3,000 - to 5,000 -fold with respect to serum. The lyophilized preparation used contained $10 \%$ protein; the remainder of the preparation consisted of salts. Whether all of the Hageman factor in the preparation was in the activated form is not clear (13).

Rabbit brain thromboplastin ${ }^{4}$ was prepared by suspending $37 \mathrm{mg}$ of thromboplastin per $\mathrm{ml}$ of $0.15 \mathrm{M}$ sodium chloride solution and warming the mixture at $45^{\circ} \mathrm{C}$ for 10 minutes in accordance with the manufacturer's directions. The thromboplastin was used without filtration. Fatty acids were obtained ${ }^{5} 99+\%$ pure. They were converted to their sodium salts by gentle warming with sodium hydroxide. Before use, the soaps were diluted with Tris buffer or barbital-saline buffer. The $\mathrm{pH}$ of the resulting mixtures was 7.4 to 7.6. The formulas of the fatty acids will be abbreviated according to the formula $\mathrm{Cx}: \mathrm{y}$, in which $\mathrm{x}$ refers to the number of carbon atoms and $\mathrm{y}$ to the number of double bonds. Calcium stearate (technical grade) was purchased from the manufacturer. ${ }^{6}$ Trisodium ethylenediaminetetraacetic acid ${ }^{7}$ was prepared by neutralizing an aqueous solution of the disodium compound with sodium hydroxide to $\mathrm{pH} 7.0$ and diluting it to the desired concentration with water.

Tris buffer $(0.15 \mathrm{M}, \mathrm{pH} 7.4)$ was prepared from tris (hydroxymethyl) aminomethane. ${ }^{8}$

Barbital-saline buffer ( $\mathrm{pH} 7.4$ ) was prepared as described before (14). Barbital-saline-citrate buffer consisted of a mixture of $85 \%$ barbital-saline buffer and $15 \% 0.13 \mathrm{M}$ trisodium citrate solution.

Dilutions of calcium chloride were made by mixing $0.05 \mathrm{M}$ calcium chloride solution in appropriate amounts of barbital-saline buffer $(0.15 \mathrm{M})$, to maintain a constant ionic strength at different concentrations of calcium ions.

Bovine thrombin 9 was dissolved at a concentration of 1,000 National Institutes of Health $U$ per milliliter in barbital-saline and then diluted further in barbital-saline as needed.

The general technique for measuring the recalcificd clotting time was to add appropriate amounts of calcium

${ }^{4}$ Difco Laboratories, Detroit, Mich.

${ }^{5}$ From Applied Science Laboratories, State College, $\mathrm{Pa}$.

${ }^{6}$ Fisher Scientific Company, Fair Lawn, N. J.

${ }^{7}$ Sequestrene $\mathrm{Na}_{2}$ supplied through the courtesy of Geigy Industrial Chemicals, New York, N. Y.

${ }^{8}$ Sigma 121, Sigma Chemical Company, St. Louis, Mo.

9 "Tropical thrombin," Parke, Davis \& Co., Detroit, Mich. chloride solution to plasma that had been incubated with the substances under test. Variations of this technique are noted with the description of each experiment.

The effect of soap on the activation of Christmas factor by activated PTA was tested by modifying a previously described two-step method (11). In this technique, the Christmas factor in hemophilic plasma was activated by activated PTA in the presence of calcium ions and soap. The reaction was stopped by the addition of barbital-saline-citrate buffer. The activated Christmas factor that had evolved was assayed, with Christmas-factor-deficient plasma as a substrate.

The influence of soap on the activation of Hageman factor by glass was determined by noting the clotting time of a mixture of native plasma and soap in Pyrex tubes (i.d. $11 \mathrm{~mm}$ ) at $25^{\circ} \mathrm{C}$. The effect of soap on inactive Hageman factor was obtained by determining the clotting time of a mixture of native plasma and soap in siliconecoated tubes (i.d. $11 \mathrm{~mm}$ ) at $37^{\circ} \mathrm{C}$.

The prothrombin time was measured by the one-stage method of Quick, Stanley-Brown, and Bancroft (15), using undiluted thromboplastin and thromboplastin diluted 1:100 with barbital-saline. The Russell's viper venom time was measured by substituting Russell's viper venom, diluted 1:10,000 with barbital-saline, for thromboplastin in the determination of the prothrombin time. The thrombin time, that is, the clotting time of a mixture of citrated plasma, bovine thrombin, and the substance to be tested, was measured by a previously described method (16). The prothrombin time, Russell's viper venom time, and thrombin time were also measured after the mixture to be tested had been incubated with plasma for one or more minutes before addition of calcium or thrombin.

All studies were performed in test tubes with an i.d. of $8 \mathrm{~mm}$ unless otherwise noted. Clotting times were performed in duplicate, and the average is reported. Concentrations recorded in the tables are those of the test substances before dilution. The data presented in the tables are typical of those obtained in repeated experiments.

\section{RESULTS}

The effect of the soaps of fatty acids upon the recalcified clotting time of normal plasma. The clot-promoting effect of the sodium soaps of fatty acids was confirmed by measuring their effect on the recalcified clotting time of normal citrated plasma. The soaps were incubated with plasma for 1 or 10 minutes at $37^{\circ} \mathrm{C}$ before the addition of calcium. As illustrated by the two separate experiments in Table I, maximal acceleration occurred with long-chain saturated fatty acids. In addition to the fatty acids shown in Table I, sodium arachidate $(\mathrm{C} 20: 0)$ at an initial concentration of $0.0032 \mathrm{mEq}$ per $\mathrm{L}$ was tested in the same way. After a preliminary incubation period of 1 
TABLE I

The effect of fatty acid soaps upon the recalcified clotting time*

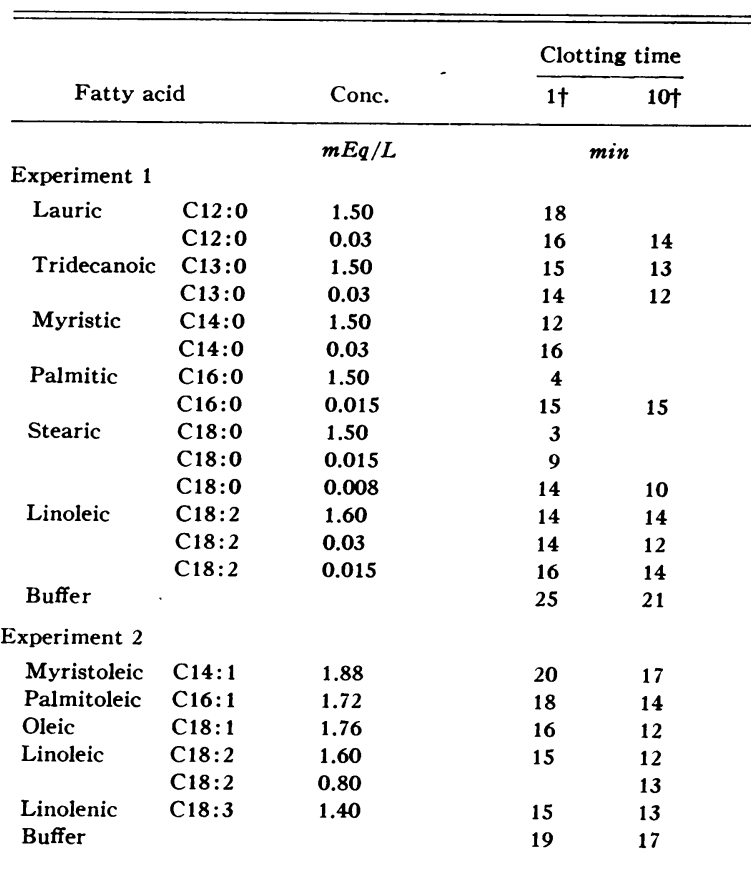

* Mixtures of $0.2 \mathrm{ml}$ of citrated normal plasma and $0.1 \mathrm{ml}$ of Tris buffer or soap were incubated in silicone-coated tubes at $37^{\circ} \mathrm{C}$ for 1 minute or 10 minutes. Then $0.1 \mathrm{ml}$ of $0.04 \mathrm{M}$ calcium chloride solution was added to each tube. The tubes were then tilted once a minute until clotting occurred.

$\dagger$ Minutes of preliminary incubation.

minute, this soap shortened the clotting time of normal plasma to 6 minutes, compared with 10 minutes in its absence. In contrast, soaps of short-chain saturated or long-chain unsaturated fatty acids either were much less active or did not shorten the recalcified clotting time. In this system, the more active soaps were effective at concentrations comparable to the concentration of free fatty acids found in normal plasma (17).

The effect of soaps on the middle and later stages of coagulation. A series of experiments was performed to determine the site of action of the clot-promoting soaps. Most of these studies were carried out with sodium arachidate. This soap, at an initial concentration of $0.0032 \mathrm{mEq}$ per $\mathrm{L}$, did not alter the rate at which fibrinogen was converted to fibrin by bovine thrombin, as tested by the thrombin time. One-tenth $\mathrm{ml}$ of soap $(0.0032$ $\mathrm{mEq}$ per L) incubated with $0.2 \mathrm{ml}$ of normal citrated plasma for 5 minutes before the addition of $0.1 \mathrm{ml}$ bovine thrombin (2.5 $\mathrm{U}$ per $\mathrm{ml})$ resulted in a clotting time of 76 seconds, as compared to 71 seconds for the buffer control. Nor did it alter the rate at which prothrombin was converted to thrombin in the presence of tissue thromboplastin or Russell's viper venom (Table II). These experiments suggested that the effect of soaps was earlier in the clotting process, perhaps affecting the rate at which thromboplastin-like activity evolved in the plasma.

The effect of soaps on the early stages of coagulation. Connor suggested that the coagulant action of soaps was mediated by their effect upon Hageman factor (6). To test this hypothesis, normal plasma was adsorbed with aluminum hydroxide and heated at $56^{\circ} \mathrm{C}$ for 30 minutes; these procedures inactivate or remove all the recognized clotting factors except Hageman factor and PTA. A mixture of such adsorbed, heated citrated plasma and sodium arachidate, incubated for 9 minutes in silicone-coated tubes, evolved clot-accelerating activity, as tested by its effect upon the recalcified clotting time of normal plasma. In contrast, no such activity appeared when soap was incubated with heated, adsorbed plasma deficient in either Hageman factor or PTA (Table III). Similar results were obtained when each experiment was performed six other times. The same lack of activity was found when soap was added to untreated plasma deficient in either of these factors.

PTA-deficient plasma contains inactive Hageman factor. Presumably, then, the clot-promoting effect of soaps cannot be attributed solely to activation of this factor. Nor did soaps seem to

TABLE II

The effect of arachidic acid soap upon the prothrombin and Russell's viper venom times*

\begin{tabular}{|c|c|c|}
\hline \multirow[b]{2}{*}{ Test substances } & \multicolumn{2}{|c|}{ Clotting time } \\
\hline & o† & $1 \dagger$ \\
\hline $\begin{array}{l}\text { Undiluted thromboplastin + soap } \\
\text { Undiluted thromboplastin }+ \text { buffer }\end{array}$ & $\begin{array}{r}s e \\
19 \\
20\end{array}$ & $\begin{array}{l}\text { nds } \\
18 \\
19\end{array}$ \\
\hline $\begin{array}{l}\text { Thromboplastin } 1: 100+\text { soap } \\
\text { Thromboplastin } 1: 100+\text { buffer }\end{array}$ & $\begin{array}{l}38 \\
37\end{array}$ & $\begin{array}{l}36 \\
36\end{array}$ \\
\hline $\begin{array}{l}\text { Russell's viper venom } 1: 10,000+\text { soap } \\
\text { Russell's viper venom } 1: 10,000+\text { buffer }\end{array}$ & $\begin{array}{l}44 \\
43\end{array}$ & $\begin{array}{l}44 \\
44\end{array}$ \\
\hline
\end{tabular}

* One-tenth $\mathrm{ml}$ of citrated normal plasma and $0.1 \mathrm{ml}$ of Tris buffer or sodium arachidate $(0.0032 \mathrm{mEq}$ per L) were incubated in silicone-coated tubes for 0 or 1 minute at $37^{\circ} \mathrm{C}$. Then $0.1 \mathrm{ml}$ of thromboplastin or Russell's viper venom and $0.1 \mathrm{ml}$ of $0.025 \mathrm{M}$ calcium chloride were added, and the clotting time was determined.

$\dagger$ Minutes of preliminary incubation. 
TABLE III

The effect of arachidic acid soap upon treated normal and abnormal flasmas*

\begin{tabular}{ccc}
\hline \hline & \multicolumn{2}{c}{ Clotting time } \\
\cline { 2 - 3 } Preliminary incubation mixture & C20:0† Buffer \\
\hline $\begin{array}{c}\text { Heated, adsorbed normal } \\
\text { plasma }\end{array}$ & 7 & 11 \\
$\begin{array}{c}\text { Heated, adsorbed Hageman- } \\
\text { factor-deficient plasma }\end{array}$ & 19 & 19 \\
$\begin{array}{c}\text { Heated, adsorbed PTA- } \\
\text { deficient plasma }\end{array}$ & 18 & 19
\end{tabular}

* One-tenth $\mathrm{ml}$ of plasma was incubated with $0.1 \mathrm{ml}$ of Tris buffer or sodium arachidate for 9 minutes in siliconecoated tubes at $37^{\circ} \mathrm{C}$. Then $0.1 \mathrm{ml}$ of $0.04 \mathrm{M}$ calcium chloride and $0.1 \mathrm{ml}$ of normal plasma were added. The tubes were then tilted once a minute until clotting occurred.

† At $0.0032 \mathrm{mEq}$ per L.

alter the activity of Hageman factor when incubated with this substance before their addition of plasma deficient in Hageman factor (Table IV). Similarly, these studies suggest that soaps are without effect upon inactive PTA in plasma. The experiments next to be described, however, indicate that soaps may influence the rate at which PTA is activated, either by Hageman factor, or "spontaneously."

The effect of soaps on activation of PTA by active Hageman factor. The soaps of long-chain saturated fatty acids were incubated with a mixture of purified activated Hageman factor and crude PTA (Table V). This mixture was then tested for its effect upon the recalcified clotting time of PTA-deficient plasma. In confirmation of earlier studies, clot-promoting activity evolved when activated Hageman factor was incubated with PTA, an effect previously attributed to the

TABLE IV

The effect of stearic acid soap upon purified activated Hageman factor*

\begin{tabular}{|c|c|c|}
\hline \multirow[b]{2}{*}{ Preliminary incubation mixture } & \multicolumn{2}{|c|}{ Clotting time } \\
\hline & $2 \dagger$ & $10 \dagger$ \\
\hline Soap + purified activated Hageman factor & \multicolumn{2}{|c|}{$\min$} \\
\hline Buffer + purified activated Hageman factor & 18 & 17 \\
\hline
\end{tabular}

* One-tenth $\mathrm{ml}$ of purified activated Hageman factor $(0.3 \mu \mathrm{g}$ protein per $\mathrm{ml}$ ) and $0.1 \mathrm{ml}$ of Tris buffer or sodium stearate $(0.75 \mathrm{mEq}$ per L) were incubated in silicone-coated tubes at $37^{\circ} \mathrm{C}$. Then $0.1 \mathrm{ml}$ o $0.025 \mathrm{M}$ calcium chloride and $0.1 \mathrm{ml}$ of Hageman-factor-deficien plasma were added. The tubes were then tilted once a minute unt + Minutes of pret
TABLE V

The effect of stearic acid soap upon the action of activated Hageman factor upon plasma thromboplastin antecedent $(P T A)^{*}$

\begin{tabular}{|c|c|c|c|c|c|c|}
\hline \multirow{2}{*}{$\begin{array}{l}\text { Preliminary incubation } \\
\text { mixture }\end{array}$} & \multicolumn{6}{|c|}{ Clotting time } \\
\hline & $0 \dagger$ & $2 \dagger$ & $10 \dagger$ & $20 \dagger$ & $30 \dagger$ & $90 \dagger$ \\
\hline & \multicolumn{6}{|c|}{$\min$} \\
\hline $\begin{array}{l}\text { Activated Hageman factor }+ \\
\text { PTA + soap, } 0.06 \mathrm{mEq} / \mathrm{L}\end{array}$ & 22 & 18 & & & 9 & 7 \\
\hline $\begin{array}{l}\text { Activated Hageman factor }+ \\
\text { PTA }+ \text { soap, } 0.015 \mathrm{mEq} / \mathrm{L}\end{array}$ & 23 & 19 & 12 & 10 & 9 & \\
\hline $\begin{array}{l}\text { Activated Hageman factor }+ \\
\text { PTA }+ \text { soap, } 0.008 \mathrm{mEq} / \mathrm{L}\end{array}$ & 24 & 20 & 13 & 11 & 10 & \\
\hline $\begin{array}{l}\text { Activated Hageman factor }+ \\
\text { PTA }+ \text { buffer }\end{array}$ & 24 & 23 & 17 & 15 & 13 & 11 \\
\hline
\end{tabular}

* Five-hundredths $\mathrm{ml}$ of purified activated Hageman factor (6.3 $\mu \mathrm{g}$ protein per $\mathrm{ml}$ ) and $0.05 \mathrm{ml}$ of Tris buffer or sodium stearate and $0.1 \mathrm{ml}$ of crude PTA diluted 1:20 in barbital saline were incubated in siliconecoated tubes at $37^{\circ} \mathrm{C}$. Then $0.1 \mathrm{ml}$ of $0.025 \mathrm{M}$ calcium chloride and $0.1 \mathrm{ml}$ of PTA-deficient plasma were added. The tubes were then tilted once a minute until clotting occurred.

activation of PTA (9). The presence of soap in the incubation mixture accelerated this reaction. Similar results were obtained when this experiment was performed eleven other times. The accelerating effect was temperature dependent. After preliminary incubation for 10 minutes at $0^{\circ} \mathrm{C}$, no acceleration could be noted in this test system; at $15^{\circ} \mathrm{C}$, suboptimal acceleration occurred. The effect of soap was apparently upon the activation of PTA, rather than upon activated PTA. If soap was added to activated Hageman factor and crude PTA after the period of preliminary incubation, no increase in clot-promoting activity was demonstrated (Table VI). Moreover, the incubation of partially purified activated PTA with soap had no effect upon the coagulation of PTA-

TABLE VI

The effect of stearic acid soab ubon Hagemanfactor-activated $P T A^{*}$

\begin{tabular}{|c|c|c|c|c|}
\hline \multirow{2}{*}{$\begin{array}{l}\text { Substance added after } \\
\text { preliminary incubation }\end{array}$} & \multicolumn{4}{|c|}{ Clotting time } \\
\hline & $2+$ & $10 \dagger$ & $30+$ & $90+$ \\
\hline & \multicolumn{4}{|c|}{$\min$} \\
\hline Soap, $0.06 \mathrm{mEq} / \mathrm{L}$, & 22 & 17 & 13 & \\
\hline Soap, $0.015 \mathrm{mEq} / \mathrm{L}$ & 22 & 17 & 13 & 12 \\
\hline Buffer & 23 & 18 & 13 & 12 \\
\hline
\end{tabular}

* Five-hundredths $\mathrm{ml}$ of purified activated Hageman factor $(6.3 \mu \mathrm{g}$ protein per $\mathrm{ml})$ and $0.1 \mathrm{ml}$ of crude PTA diluted $1: 20$ in barbital saline were incubated in siliconecoated tubes at $37^{\circ} \mathrm{C}$. Then $0.05 \mathrm{ml}$ of Tris buffer or sodium stearate, $0.1 \mathrm{ml}$ of $0.025 \mathrm{M}$ calcium chloride, and $0.1 \mathrm{ml}$ of PTA-deficient plasma were added. The tubes were then tilted once a minute until clotting occurred.

$\dagger$ Minutes of preliminary incubation. 
TABLE VII

The effect of stearic acid soap upon partially purified activated PTA*

\begin{tabular}{llll}
\hline \hline \multirow{2}{*}{$\begin{array}{c}\text { Preliminary incubation } \\
\text { mixture }\end{array}$} & \multicolumn{2}{c}{ Clotting time } \\
\cline { 2 - 3 } & 0+ & 10† \\
\hline & \multicolumn{3}{c}{$\min$} \\
Soap + activated PTA & 16 & 19 \\
Buffer + activated PTA & 16 & 19 \\
\hline
\end{tabular}

* One-tenth $\mathrm{ml}$ of partially purified activated PTA $(0.3$ $\mu \mathrm{g}$ protein per $\mathrm{ml}$ ) and $0.1 \mathrm{ml}$ of Tris buffer or sodium stearate $(0.75 \mathrm{mEq} / \mathrm{L})$ were incubated in silicone-coated tubes at $37^{\circ} \mathrm{C}$. Then $0.1 \mathrm{ml}$ of $0.025 \mathrm{M}$ calcium chloride and $0.1 \mathrm{ml}$ of PTA-deficient plasma were added. The tubes were then tilted once a minute until clotting occurred. $\dagger$ Minutes of preliminary incubation.

deficient plasma (Table VII), or upon the activation of Christmas factor in hemophilic plasma (Table VIII).

The soaps of long-chain saturated fatty acids were also incubated with a mixture of purified activated Hageman factor and Hageman-factordeficient plasma. This plasma served as a source of inactive PTA. The recalcified clotting time of the mixture was then determined (Table IX). Clot-promoting activity evolved, and the presence of soap in the incubation mixture accelerated this reaction.

The effect of soaps on crude PTA. The experiments described can be interpreted to mean either that soaps accelerate the activation of PTA by activated Hageman factor, or that they activate PTA directly. Previously, we had noted that

TABLE VIII

The effect of stearic acid soap upon the activation of Christmas factor by $P T A^{*}$

\begin{tabular}{ccccc}
\hline \hline \multirow{2}{*}{$\begin{array}{c}\text { Test sub- } \\
\text { stance added }\end{array}$} & \multicolumn{4}{c}{ Clotting time } \\
\cline { 2 - 5 } & $0 \dagger$ & $4 \dagger$ & $10 \dagger$ & $16 \dagger$ \\
\hline Soap & 8.0 & 5.5 & 5.0 & 5.5 \\
Buffer & 8.0 & 6.0 & 5.5 & 5.5
\end{tabular}

* Five-tenths $\mathrm{ml}$ of citrated hemophilic plasma, 0.5 $\mathrm{ml}$ of partially purified activated PTA $(0.08 \mu \mathrm{g}$ protein per $\mathrm{ml}$ ), $0.5 \mathrm{ml}$ of $0.01 \mathrm{M}$ calcium chloride, and $0.5 \mathrm{ml}$ barbitalsaline buffer or sodium stearate $(2.0 \mathrm{mEq}$ per L) were incubated in silicone-coated tubes at $37^{\circ} \mathrm{C}$. At intervals, $0.4 \mathrm{ml}$ was transferred by silicone pipettes to siliconecoated tubes containing $0.7 \mathrm{ml}$ barbital-citrate-saline. Then $0.1 \mathrm{ml}$ of this resulting mixture, $0.1 \mathrm{ml}$ of citrated Christmas-factor-deficient plasma, and $0.1 \mathrm{ml}$ of $0.04 \mathrm{M}$ calcium chloride were mixed in silicone-coated tubes. The tubes were then tilted every one-half minute until clotting occurred.

$\dagger$ Minutes of preliminary incubation. crude PTA, prepared by elution from carboxymethylcellulose, became active spontaneously in the absence of added activated Hageman factor (9).

One-tenth ml crude PTA, incubated for $10 \mathrm{~min}$ utes in silicone-coated tubes with $0.1 \mathrm{ml}$ sodium stearate $(0.75 \mathrm{mEq}$ per $\mathrm{L})$, had a marked accelerating effect upon the recalcified clotting time of PTA-deficient plasma, as demonstrated by a clotting time of 5 minutes, compared to 11 minutes when buffer was substituted for the soap. This experiment was repeated twelve times, and the same qualitative result was obtained on each occasion. If the soap was added to crude PTA after the preliminary incubation period, acceleration

TABLE IX

The effect of stearic acid soap upon the action of activated Hageman factor upon Hageman-factor-deficient plasma*

\begin{tabular}{lcccccc}
\hline & \multicolumn{5}{c}{ Clotting time } \\
\cline { 2 - 6 } Preliminary incubation mixture & $\frac{1}{2} \dagger$ & $1 \dagger$ & $2 \dagger$ & $5 \dagger$ & $10 \dagger$ \\
\hline $\begin{array}{c}\text { Activated Hageman factor } \\
\quad+\text { soap, 0.6 mEq/L }\end{array}$ & 8 & 8 & 6 & 7 & 7 \\
$\begin{array}{c}\text { Activated Hageman factor } \\
+ \text { buffer }\end{array}$ & 12 & 10 & 8 & 9 & 10 \\
\hline
\end{tabular}

* Two and two-tenths $\mathrm{ml}$ of Hageman-factor-deficient plasma, $1.1 \mathrm{ml}$ barbital-saline or sodium stearate, and 1.1 $\mathrm{ml}$ purified activated Hageman factor $(2.5 \mu \mathrm{g}$ protein per $\mathrm{ml}$ ) were incubated in silicone-coated tubes at $37^{\circ} \mathrm{C}$. At intervals, $0.4 \mathrm{ml}$ of this mixture was transferred in duplicate with silicone-coated pipettes to silicone-coated clotting tubes. Then $0.1 \mathrm{ml}$ of $0.04 \mathrm{M}$ calcium chloride was added, and the tubes were tilted once a minute until clotting occurred.

$\dagger$ Minutes of preliminary incubation.

did not occur. The effect of soaps upon crude PTA was confirmed in experiments in which Hageman-factor-deficient plasma was the substrate in a similar test system. When crude PTA and sodium stearate $(1.0 \mathrm{mEq}$ per $\mathrm{L})$ were incubated for 10 minutes, the mixture shortened the recalcified clotting time of Hageman-factor-deficient plasma from 52 to 14 minutes, indicating again that the effect of soaps did not require the presence of Hageman factor.

The effect of soaps on the initiation of clotting of native plasma in silicone-coated and glass tubes. From the preceding experiments, one would anticipate that the clotting time of native plasma either in silicone-coated or in glass tubes would be shortened by the addition of soap. In fact, 
however, under these conditions clotting was not accelerated (Table $\mathrm{X}$ ). The difference between the effect of soaps upon native plasma or citrated plasma may relate to the concentration of calcium at the time the soap was added. Calcium chloride solution added to citrated plasma before the addition of soaps inhibited their clotpromoting effect (Table XI). This explanation may not be entirely satisfactory. Although the final concentration of calcium $(0.0017 \mathrm{M})$ needed for inhibition in the preliminary incubation mixture was lower than that normally found in human plasma, the inhibition was not complete.

Nevertheless, calcium stearate suspended in barbital-saline buffer at an initial concentration of $2 \mathrm{mEq}$ per $\mathrm{L}$ did not accelerate clotting significantly. After a preliminary incubation period of 5 minutes, the recalcified clotting time of a mixture of normal plasma and calcium stearate was 15 minutes, whereas that of normal plasma alone was 19 minutes. The same plasma mixed with an equivalent concentration of sodium stearate clotted in 3 minutes when tested in the same way.

Failure to demonstrate an accelerating effect of soaps on Christmas factor activation might have resulted from this inhibition by calcium ions, which are a necessary part of this experiment. The ratio of soap concentration to calcium concentration, however, should have been sufficient to permit the soaps to remain effective. Therefore, artifactual inhibition by added calcium ions should not have occurred.

The recalcified clotting time of normal plasma prepared from blood to which one-ninth vol of $0.05 \mathrm{M}$ trisodium ethylenediaminetetraacetic acid

TABLE $X$

The effect of stearic acid soap upon the clotting time o, native plasma*

\begin{tabular}{ccc}
\hline \hline \multirow{2}{*}{ Test mixture } & \multicolumn{2}{c}{ Clotting time } \\
\cline { 2 - 3 } & $\begin{array}{c}\text { Glass } \\
\left(25^{\circ} \mathrm{C}\right)\end{array}$ & $\begin{array}{c}\text { Silicone } \\
\left(37^{\circ} \mathrm{C}\right)\end{array}$ \\
\hline Native plasma + soap & $\min$ & hours \\
Native plasma + buffer & 11 & $>24$ \\
& 10 & $>24$
\end{tabular}

* One-tenth $\mathrm{ml}$ of sodium stearate $(2.0 \mathrm{mEq}$ per $\mathrm{L})$ or bar bital-saline buffer and $2.2 \mathrm{ml}$ of native plasma were mixed together in silicone-coated tubes. Then $0.5 \mathrm{ml}$ was transferred by silicone-coated pipettes to Pyrex or siliconecoated tubes (i.d. $11 \mathrm{~mm}$ ), and the clotting time was determined.
TABLE XI

The effects of calcium upon the accelerating action of soaps*

\begin{tabular}{ccc}
\hline \hline & \multicolumn{2}{c}{ Clotting time } \\
\cline { 2 - 3 } Ca concentrationt & C18:0 & Buffer \\
\hline$M$ & \multicolumn{2}{c}{ min } \\
0 (buffer) & 8 & 17 \\
0.001 & 7 & 19 \\
0.002 & 10 & 21 \\
0.005 & 16 & 19 \\
0.010 & 15 & 17 \\
0.015 & 13 & 16 \\
0.020 & 14 & 18 \\
0.025 & 14 & 15
\end{tabular}

* Five-hundredths $\mathrm{ml}$ of purified activated Hageman factor $(3.1 \mu \mathrm{g}$ protein per $\mathrm{ml}), 0.1 \mathrm{ml}$ of varying concentrations of calcium chloride, $0.05 \mathrm{ml}$ of Tris or sodium stearate $(1.5 \mathrm{mEq}$ per $\mathrm{L})$, and $0.1 \mathrm{ml}$ of crude PTA diluted $1: 10$ in barbital-saline were incubated in silicone-coated tubes for 10 minutes at $37^{\circ} \mathrm{C}$. Then $0.1 \mathrm{ml}$ of calcium chloride in concentration sufficient to raise the total concentration of calcium to $0.025 \mathrm{M}$ and $0.1 \mathrm{ml}$ of PTA-deficient plasma were added. The tubes were then tilted once a minute until clotting occurred.

$\dagger$ Of volume added to preliminary concentration mixture.

had been added was tested to determine if citrate influenced the clot-promoting effect of soaps. After a preliminary incubation period of 5 minutes, sodium stearate at an initial concentration of 2 $\mathrm{mEq}$ per $\mathrm{L}$ shortened the clotting time from 45 to 7 minutes. Thus, the clot-promoting effect of sodium stearate was manifest when calcium ions were chelated not only to citrate but also to ethylenediaminetetraacetic acid.

\section{DISCUSSION}

Attempts to establish the existence of a "hypercoagulable" state in thrombotic disease-that is, an increased propensity for the blood to clothave met with dubious success (18-20). Since disturbed lipid metabolism has been associated with such disorders (21), efforts have been made to relate alterations in the lipid constituents of plasma to the pathogenesis of thrombosis. Thus, Connor and Poole $(5,6)$ demonstrated that sodium soaps of long-chain saturated fatty acids dramatically accelerated the recalcified clotting time of whole blood in silicone-coated tubes or in rotating plastic loops. The concentrations of fatty acids that were effective were of the same order of magnitude as those found in normal human plasma. These data suggested that elevations in the concentration of free fatty acids in plasma 
might be important in the genesis of intravascular thrombosis. Since the sodium soaps did not accelerate the clotting of duck blood, which lacks detectable Hageman factor (22), Connor attributed their effect upon mammalian blood to the activation of this substance. He interpreted the action of soaps to be analogous to that of glass and similar surfaces known to initiate clotting by activating Hageman factor (6). Connor's interpretation has been supported by Mibashan and Didisheim (23) and by Margolis (24).

In the present study, the clot-promoting properties of the soaps of long-chain saturated fatty acids were confirmed by testing their effect upon the recalcified clotting time of human citrated plasma. Suitable studies demonstrated that the site of action of the soaps was not upon Hageman factor, as had been postulated, but rather upon PTA, a substance also deficient in duck plasma (25). The soaps appear to accelerate the activation of PTA. Previously, PTA has been shown to be activated in vitro by activated Hageman factor or "spontaneously" (9). The effect of soaps was demonstrable either if activated Hageman factor was added to inactive PTA, or if the PTA had undergone partial activation "spontaneously." On the other hand, the soaps appeared to be without effect upon inactive PTA. At first glance, this view may seem paradoxical, since soaps accelerated the clotting of normal platelet-deficient plasma collected and tested in silicone-coated apparatus. In fact, however, such plasma always clotted upon recalcification in the absence of added soaps under the conditions of our studies. Thus, these normal plasmas either contained some activated PTA, or this activity generated during the course of the experiment.

The contrary view, that soaps activate Hageman factor, was supported by Margolis by experiments with plasma deficient in this substance (24). Margolis showed that the clot-promoting effect of soaps could be partially inhibited by mixing the soap for 30 seconds with Hageman-factordeficient plasma before the addition of normal plasma. He interpreted these experiments to mean that the Hageman-factor-deficient plasma, known to contain inhibiting properties (22), specifically blocked the action of soaps upon the Hageman factor contained in the normal plasma. We have been able to confirm these experiments but find in addition that the action of soaps can be inhibited equally by plasma deficient in PTA but not in Hageman factor. Whatever the mechanism through which these inhibitions occurred, then, they did not seem to depend upon the absence of Hageman factor. Interestingly, plasma obtained from patients with classic hemophilia or Christmas disease did not inhibit the action of soaps (26). The mechanism through which soaps manifest their action upon PTA is unknown. Whether this effect is related to micelle formation as postulated by Connor (6) was not determined. Nor is it necessary that their action be directly upon the PTA molecule. Equally plausible is an action upon a clotting factor, not yet recognized, mediating the activation of PTA by activated Hageman factor.

Connor and Poole were aware that the maximal clot-promoting effect of soaps upon citrated whole blood could not be demonstrated unless a minute elapsed before the mixture was recalcified (5). In our own experiments, no clot-promoting activity was detectable when the soaps were added to native plasma, that is, plasma that had not been decalcified. Moreover, when calcium chloride solution was added to the soaps of saturated fatty acids before the addition of plasma, the clot-promoting effect of the soaps was reduced. Similar results have been reported by Margolis (24). In our experiments, calcium did not inhibit completely the procoagulant action of soaps. The presence or absence of calcium ions, therefore, may not be the sole determinant for the difference in behavior of soaps upon native plasma as opposed to citrated plasma. How calcium ions inhibit the effect of soaps was not learned. The fact that calcium stearate was shown not to accelerate clotting significantly provides evidence for one explanation, that is, that calcium ions react with sodium soaps to form inactive calcium soaps, a view previously expressed by Margolis (24).

Tests to determine whether soaps influenced the activation of Christmas factor by activated PTA were performed in the presence of calcium ions, since these are needed for this step to proceed (11). The inhibitory effect of calcium ions upon the action of sodium soaps suggested that our systems could not detect an influence of soaps upon the activation of Christmas factor. In fact, however, soaps were without effect upon the ac- 
tivation of Christmas factor when tested in the presence of calcium ions at a concentration below that which was inhibitory (Table VIII). These observations make it unlikely that the techniques used masked an effect of soaps upon the activation of Christmas factor.

The effect of soaps upon the activation of PTA may help illuminate the puzzling problem of the asymptomatic nature of Hageman trait. In this disorder, the plasma lacks detectable Hageman factor, and gross abnormalities of clotting are readily detectable in vitro. Nonetheless, patients with Hageman trait have few if any evidences of a hemostatic defect. Hageman factor, once activated, apparently initiates clotting in glass tubes by activating PTA. Previously, partially purified preparations of PTA have been found to have undergone "spontaneous" activation in the absence of added activated Hageman factor. Thus, an alternative pathway for the initiation of clotting, not necessarily dependent upon the presence of Hageman factor, may exist. The present study, in which the soaps of long-chain saturated fatty acids accelerate the activation of PTA in the absence of added Hageman factor, supports this view. Presumably, from the evidence presented, such an alternate pathway would not be dependent upon the action of soaps in vivo. Nevertheless, these observations fortify the view that hemostasis in patients with Hageman trait is dependent upon the existence of alternative ways of activating PTA.

These experiments, then, confirm the clot-promoting effect of soaps and localize their action to the activation of PTA. What significance these observations have for the pathogenesis of thrombotic states is uncertain. The failure of soaps to accelerate the clotting of native plasma makes it seem doubtful that the free fatty acids of human plasma are of importance in the development of intravascular thrombi. The possibility is by no means ruled out, since large increases in concentration of free fatty acids in localized areas may occur and conceivably overcome inhibition to any clot-promoting effect.

\section{SUM M ARY}

The in vitro procoagulant effect of the sodium soaps of long-chain saturated fatty acids appears to be due to acceleration of the activation of plasma thromboplastin antecedent (PTA). The presence of Hageman factor was not necessary for this effect, suggesting that alternate pathways for the activation of PTA exist. Calcium chloride solution partially inhibited the acceleration by soaps. The data presented suggest that the clot-promoting properties of the soaps are unlikely to be significant under the conditions present in circulating blood. Thus, the concept that the free fatty acids of human plasma are of importance in the development of intravascular thrombi seems doubtful.

\section{ACKNOWLEDGMENT}

Plasmas deficient in PTA and Christmas factor were provided through the courtesy of Dr. R. Rosenthal and Dr. T. Spaet, respectively.

\section{REFERENCES}

1. Stuber, B., and R. Heim. Ueber Fettsäuren und Blutgerinnung, zugleich eine chemische Erklärung des Gerinnungsvorganges. Münch. med. Wschr. 1914, 61, 1661.

2. Poole, J. C. F. The effect of certain fatty acids on the coagulation of plasma in vitro. Brit. J. exp. Path. 1955, 36, 248.

3. Pilkington, T. R. E. The effect of fatty acids and detergents on the calcium clotting time of human plasma. Clin. Sci. 1957, 16, 269.

4. O'Brien, J. R. The effect of some fatty acids and phospholipids on blood coagulation. Brit. J. exp. Path. 1957, 38, 529.

5. Connor, W. E., and J. C. F. Poole. The effect of fatty acids on the formation of thrombi. Quart. J. exp. Physiol. 1961, 46, 1.

6. Connor, W. E. The acceleration of thrombus formation by certain fatty acids. J. clin. Invest. 1962, 41, 1199.

7. Fredrickson, D. S., and R. S. Gordon, Jr. Transport of fatty acids. Physiol. Rev. 1958, 38, 585.

8. Kirshbaum, A., S. Bellet, R. F. Coplan, and L. J. Feinberg. Effect of cigarette smoking on free fatty acids in patients with healed myocardial infarction. Amer. J. Cardiol. 1962, 10, 204.

9. Ratnoff, O. D., E. W. Davie, and D. L. Mallett. Studies on the action of Hageman factor: evidence that activated Hageman factor in turn activates plasma thromboplastin antecedent. J. clin. Invest. 1961, 40, 803.

10. Conley, C. L., R. C. Hartmann, and W. I. Morse. II. The clotting behavior of human "platelet-free" plasma: evidence for the existence of a "plasma thromboplastin." J. clin. Invest. 1949, 28, 340.

11. Ratnoff, O. D., and E. W. Davie. The activation of Christmas factor (factor IX) by activated plasma 
thromboplastin antecedent (activated factor XI). Biochemistry 1962, 1, 677.

12. Kingdon, $H$. Personal communication.

13. Ratnoff, O. D., and E. W. Davie. The purification of activated Hageman factor (activated factor XII). Biochemistry 1962, 1, 967.

14. Ratnoff, O. D., and J. E. Colopy. A familial hemorrhagic trait associated with a deficiency of a clotpromoting fraction of plasma. J. clin. Invest. 1955, 34, 602.

15. Quick, A. J., M. Stanley-Brown, and F. W. Bancroft. A study of the coagulation defect in hemophilia and in jaundice. Amer. J. med. Sci. 1935, 190, 501.

16. Ratnoff, O. D. An accelerating property of plasma for the coagulation of fibrinogen by thrombin. J. clin. Invest. 1954, 33, 1175.

17. Dole, V. P., A. T. James, J. P. W. Webb, M. A. Rizack, and M. F. Sturman. The fatty acid patterns of plasma lipids during alimentary lipemia. J. clin. Invest. 1959, 38, 1544.

18. Merskey, C., H. Gordon, H. Lackner, V. Schrire, B. J. Kaplan, R. Sougin-Mibashan, H. L. Nossel, and A. Moodie. Blood coagulation and fibrinolysis in relation to coronary heart disease. A comparative study of normal white men, white men with overt coronary heart disease, and normal Bantu men. Brit. med. J. 1960, 1, 219.

19. Rapaport, S. I. Possible relationships between clotting factors in vitro and intravascular clotting. Angiology 1959, 10, 391.

20. Ingram, G. I. C., R. Biggs, and P. Armitage. Laboratory tests for incipient thrombosis. J. clin. Path. $1953,6,46$.

21. Leary, T. Atherosclerosis, the important form of arteriosclerosis, a metabolic disease. J. Amer. med. Ass. 1935, 105, 475.

22. Ratnoff, O. D., and J. M. Rosenblum. Role of Hageman factor in the initiation of clotting by glass. Evidence that glass frees Hageman factor from inhibition. Amer. J. Med. 1958, 25, 160.

23. Mibashan, R. S., and P. Didisheim. Activation of Hageman clotting factor (HF) by long-chain saturated fatty acids (LSFA). Fed. Proc. 1963, 22, 163.

24. Margolis, J. Activation of Hageman factor by saturated fatty acids. Aust. J. exp. Biol. med. Sci. 1962, 40, 505.

25. Wartelle, O. Les facteurs prothromboplastiques du sang de poule et de quelques mammifères. Doctoral thesis, University of Paris, 1958.

26. Botti, R. E., and O. D. Ratnoff. Unpublished observations. 